\title{
The Enlightenment of American Higher Education Personnel Training Internationalization to Chinese Higher Education
}

\author{
Yang Liu ${ }^{1, a^{*}}$, Daying Liu ${ }^{2, \mathrm{~b}}$, \\ ${ }^{1}$ The college of horticulture and landscape \\ ${ }^{2}$ The department of basic science \\ Tianjin Agricultural University, Tianjin, China \\ a782292767@qq.com*, bliudaying03@163.com,
}

\author{
Lu Ding ${ }^{3, c}$ and Wenbi Zhu ${ }^{4, d}$ \\ ${ }^{3}$ The college of agronomy \& resources and environment \\ ${ }^{4}$ The department of teaching affairs \\ Tianjin Agricultural University, Tianjin, China \\ c935469309@qq.com, ${ }^{\mathrm{d}}$ zhuwenbi@tjau.edu.cn
}

\begin{abstract}
International development model of higher education personnel training has an important impact on the development of higher education. On the basis of experience of the internationalization of educating higher talents in the United States and combining with the present situation of China, we proposed the China's specific development path of talent training internationalization in higher education. We hope the development path putting forward can make some contribution to the internationalized development program making and implementation in China, specifically in the field of agriculture.
\end{abstract}

Keywords-Higher education; Internationalization; Personnel training; Enlightenment

\section{INTRODUCTION}

The globalization of economic development Claims for the internationalization of higher education, the concept of running a university, the elements of running a school and the behavior of running school gradually cross the international boundaries and interaction with each other. Moreover, those crossing and interactions appear in many educational activities including teaching, research, and even university service. The United States has played a vanguard role in the internationalization of higher education. Through the development of the policies of for the internationalization of talent training, and adopting the strategies suitable for the national conditions, United States has made positive contribution to studying abroad, teachers communication, the development of education curriculums, transnational education, foreign language teaching and many other fields. It has greatly accelerated the pace of the development of international talent cultivation in higher education, and the United States has got remarkable results ${ }^{[1]}$. Our country also attaches great importance to the development trend of higher education internationalization. In the Chinese $12^{\text {th }}$ 'Five-Year' development strategy, the development of university education internationalization is highlighted ${ }^{[2]}$. Agricultural university is an important part of higher education in China. Therefore, there is an urgent need for the development of agricultural university education internationalization. Through the internationalization of higher education personnel training, the new concepts and advanced methods and successful experience of higher education are gained from developed countries ${ }^{[3]}$. In order to accelerate and achieve the agricultural university education internationalization of our country, we should learn from the successful experience of the internationalization of higher education developed by United States, and combine with the actual situation of Chinese higher education, some suggestions available for reference are put forward.

\section{THE INTERNATIONALIZATION STRATEGIES OF AMERICAN HIGHER EDUCATION PERSONNEL TRAINING}

\section{A. Promote the students' international exchange}

In order to reverse the adverse effects of the economic downturn on American higher education, the U. S. government designed some international policies for personnel training, and signed a series of international cooperation agreements to promote students international exchange ${ }^{[4]}$.

(a) Passing new bills to support and encourage students to study abroad. The new bill admits that the diplomas obtained abroad by students can be included in education credits.

(b) Developing the international education programs and expanding international exchanges and cooperation. For example, the U. S. government promotes the students to study abroad through the signing of the students exchange programs with foreign universities.

(c) Signing the international cooperation agreements and reinforcing international personnel training. For example, the U. S. Secretary of State Hilary Clinton formally proposed the one hundred thousand plan and signed some relevant agreements, in Beijing in May 2010, to devote greater efforts to increase the American short-term students visits to Chinese universities. At the same time, because of its prominent status in international education, the United States has the largest number of foreign students in the world during the implementation of the above international education strategies. It was reported that the number of students leaving from mainland to the United States is up to 127,628 in 2010 , which is surged by $30 \%$, compared with 2009. 


\section{B. Support the teachers' international communication}

$46 \%$ of American colleges and universities support the teachers to study abroad or international exchange in 2002, while, rising to $58 \%$ in $2006 ; 27 \%$ the teachers funded by colleges and universities study abroad in 2001 in the United States, 5 years later increased by $12 \%$. The increased support rate is closely related to the corresponding policies of American colleges and universities, which can be summarized as the following aspects:

(a) Develop the government fund projects, for example, the Fulbright Program. The Fulbright Program is the flagship international educational exchange program sponsored by the U.S. government and is designed to "increase mutual understanding between the people of the United States and the people of other countries". With this goal as a starting point, the Fulbright Program has provided almost 300,000 participants-chosen for their academic merit and leadership potential-with the opportunity to study, teach and conduct research, exchange ideas and contribute to finding solutions to shared international concerns.

(b) Establish exchange programs or cooperative relations with colleges and universities. There is a successful example for the school exchange program established between State University of New York and Peking University.

(c) Make the talent attraction policies. United States provides the preferential treatment and create excellent study or research environment to attract famous scientists in the world leaving for American colleges and universities to engage in teaching and research work.

(d) Finance the teachers to study or research overseas. A certain number of the teachers, granted by the overseas research fund, are encouraged to engage in scientific research or carry out academic exchange activities. There are a variety of the teachers' overseas grants to finance the experts and scholars to participate in international academic conferences, international studies and researches in Michigan State University, etc.

(e) Bring the new teachers with international experience. The colleges and universities can recruit more new teachers with international experience. More than half of the American four-year colleges and universities have recruited the new teachers with international experience, actually ${ }^{[5,6]}$.

\section{Emphasis on the internationalization of education curriculums}

The main methods of internationalization of education curriculums in American colleges and universities are as follows:

(a) Focus on the international perspective and develop the new interdisciplinary courses. In order to bring the international course contents together, these new interdisciplinary courses are jointly undertaken by the teachers of different subjects. Thus, the students broaden their international horizons through learning. One course, for example, global dependence, developed by University of Michigan, includes four parts, namely, international trade history, economics and management relations, cultural competition and the meaning of one world. The course is shared by more than ten teachers of different subjects, offered a certain number of class discussions, and aimed at training the students to understand trade with international perspective.

(b) Attach great importance to the professional education and integrating internationalization into professional education. There is a typical case of the international professional education. In University of Rhode Island, the international engineering courses include German and engineering, with the duration of five years. After five-year study and graduation, the graduates can obtain double bachelor degrees in Engineering Science and German literature.

(c) Innovative designs of the international curriculums. According to school conditions, combined with international training objectives, the teachers develop innovative design of new courses. In Warren Wilson College, the curriculum of international development designed by the teachers is composed of two parts, namely, work and service. After completing the six-month required courses, the design courses are usually completed in rural administrative areas in 2-4 months under the teachers' guide. The teachers and students can engage in specific work or provide professional and technical services in local.

(d) Make full use of science and technology, especially information technology, which is conducive to the construction of international courses. With Peking University and Beijing Film Academy, University of Hawaii develops a remote Chinese teaching course with the benefit of Internet, by the interactive network TV. It provides a great convenience for the American students learning Chinese and Chinese culture ${ }^{[5,7]}$.

\section{Carry conditionally out the transnational education.}

It is optional to carry out transnational higher education in United States, the key is to verify the international school qualification and ability to control the quality of transnational education and maintain the United States higher education brand. Therefore, the United States Higher Education Accreditation Commission promulgated the international certification standards in 2001, which is emphasizing that the foreign universities, in transnational higher education cooperation with the United States, must meet or better than native level of higher education. Thus, it ensures the sovereignty of domestic education and the quality of transnational higher education. In this guarantee conditions, United States carry actively out transnational cooperation in running schools or establishing the international campuses. According to the Chinese Ministry of education statistics, the cooperation of running school project between the United States and China has been up to 154 at the end of 2002. It is generally established the school cooperation through setting up branch campuses. New York University in Shanghai, which starts to recruit new students from the fall of 2013, is the successful school cross-border cooperation case between New York University and Shanghai East China Normal University ${ }^{[5}$ 8]

\section{E. Attaching importance to foreign language teaching and learning.}

English, as the native language of United States, is the first general language in the world. American colleges and universities are not interested in the non-English teaching and learning. However, the 9.11 Incident changed the U. S. concept and recognized the importance of foreign language, especially in information communication and safe-guarding national security. The U.S. president announced the national language security action plan in early 2006 , which is mainly to determine the expansion of Fulbright Foreign Language Teaching Assistant Program. It allows foreigners who speak 'key languages' to engage in language teaching in American colleges and universities, besides, the number of foreign language learning abroad with an increase of an annual growth rate of 150 students. Furthermore, the Gilman International Scholarship Program, which is granted to learn the 'key languages', will increase the number of undergraduate students 
funded up to 200. In addition, in order to encourage the students to learn a foreign language, the American universities provide the students with practical language learning courses which are associated with credit. St. Olaf College permits the students to learn some courses in foreign language; while, 1 credits for students studying languages abroad are equivalent to the credits of 3 credits in English in Syracuse University ${ }^{[5,9]}$.

\section{ENLIGHTENMENT OF AMERICAN HIGHER EDUCATION INTERNATIONAL PERSONNEL TRAINING TO CHINESE AGRICULTURAL HIGHER EDUCATION}

The internationalization of American higher education and its successful experience provide an important reference for the internationalization of higher education in China. On the current situation, the internationalization of higher education in China has developed rapidly. Meanwhile, basic education is relatively strong. However, the internationalization concept of higher education in China is still not enough, for instance, lack of innovative management mechanism, imperfect software and hardware construction ${ }^{[10,11]}$, agricultural higher education is still lack of attention, and the cultivation of agricultural innovative talents is more urgent ${ }^{[12]}$. Combined with our actual situation of higher education, it is necessary to encourage actively teachers and students to carry out extensive international exchanges. The internationalization and global contents are brought in university teaching, scientific research, service and other aspects. Focus on the diversity and heterogeneity of students, we provide the students with an internationally diverse learning environment to train the competitive globally citizens. At the same time, we should take into account and maintain the characteristics of the Chinese nation cultures, create a more reasonable education system and mechanism, and develop the higher education suitable for our national conditions, especially the agricultural higher education.

\section{A. Pay more attention to the foreign students education.}

American foreign students education has not only won a remarkable international status for American education, but also the costs associated with international students education brought great benefits to the United States. Chinese culture education has a long history, many institutions of higher education, and rapid economic development, which meet the basic conditions for the development of foreign students' education. The Chinese higher education, especially agricultural higher education, should pay more attention to the following aspects:

(a) Convert ideas: clear the goal of higher education internationalization and pay more attention to training the students' international ideas;

(b) Perfect the system: improve the various conservative rules and regulations within the school, strengthen the scientific management of foreign affairs, and formulate and revise the regulations and regulations on the administration of foreign students;

(c) Create conditions: Creation and design of international, multicultural and the characteristics of Chinese culture classroom teaching, offer more scholarships, accommodation facilities and social practice opportunities, to increase the attraction of international students;

(d) Promote international exchange: Sign the intercollegiate cooperation agreements, strengthen exchange with other countries, especially the agricultural developed countries, and introduce to the teachers and students with international background, etc.; (e) Strengthen the security mechanism: In the process of strengthening foreign students' education, we should standardize the institutions of studying abroad, establish and perfect the evaluation institution and index system.

\section{B. Strengthen international exchange of the teachers.}

American colleges and universities have a variety of forms of funding programs to invite world-famous experts and scholars to visit and research in the United States and to encourage domestic teachers to visit and study overseas. High quality experts and teachers play an important role in improving the internationalization of education. We should learn from the experience of the United States, build friendly relationships with foreign universities, bring in more foreign famous experts by the exchange scholars and other forms, and learn the humanistic spirit, educational ideas, academic thoughts, science and technology, management experience from developed countries to promote the internationalization of the Chinese teachers, improve the teachers' academic research ability and administrative staff's management ability. We also encourage domestic university teachers to communicate and cooperate with foreign famous universities, send some expert teachers to study abroad and engage in cooperative research in the fields of modern agriculture, lowcarbon agriculture, and special agriculture. Thus, not only foreign advanced ideas, experience and technology can be brought back to China, but also the Chinese outstanding culture can be spread around the world. The latest advanced education and research resources are acquired by keeping track of the forefront of higher education development in the world. Besides, we expand the influence of Chinese teachers in international academic exchanges.

\section{Construct the international curriculum system.}

We should learn the good experience from the United States such as the introduction, digestion, absorption and utilization of the advanced ideas of Western Europe, and solve the problem of curriculum internationalization in higher education based on the Chinese situation. First of all, the international concept can be considered as soon as possible into the school's overall development program and the talent training objectives. The colleges and universities should actively offer the courses on world civilization, international relations, international politics and world economy with international characteristics, and are encouraged to actively introduce, adapt and update teaching materials. Through the practical construction and concrete implementation of the international curriculum system, the international vision and ability of teachers and students are expanded and cultivated. Secondly, the development internationalization of talent training should be regarded as one of the important indicators of curriculum rating. The courses should be evaluated by the internationally recognized, comparable evaluation quality standards. Furthermore, the language teaching and regional research curriculum construction in East Asian countries should be strengthened in foreign language teaching of Chinese colleges and universities to avoid the unilateralism of international regional studies. The main approaches of internationalization curriculum system are as follows ${ }^{[13]}$ :

(a) Teach in small class. Small class teaching is generally used in international universities. The number of students in small class is less than 30 and at least 1 . This model can enhance the teachers' teaching leadership and control ability.

(b) Internationalization in classroom layout. The internationalization of classroom layout is the basic 
environment of teaching internationalization, and its basic layout is that teachers are in an oblique angle in the classroom, similar to the position of the host, while the students sit in groups around one table. The equal layout is conducive to the realization of teaching democratization atmosphere.

(c) Interactive teaching. Teaching interaction, which is one of the characteristics of the internationalization of curriculum teaching, is carrying out the teaching atmosphere and the democratization of students through the interaction between active teachers, students and students. The interaction can be carried out not only in class, but also after-school, especially after-school interaction based on the developed network technology.

(d) Focus on knowledge development. Paying attention to knowledge development is the basic connotation of teaching internationalization. The new knowledge is introduced into the classroom in time to make the classroom teaching full of vitality and enable students to cognitive new knowledge.

\section{Strengthening education internationalization by network technologies.}

On the one hand, with the rapid development of modern information technology, our country should increase the funding investment, construct specialized internet, and carry out online education. For example, the internet telephone and network courses could be applied to international teaching by internet work. As another example, in order to achieve resource sharing, we can establish contact with foreign colleges and universities, and build inter-school resource sharing platform through the internet, or even provide elective courses through the internet. On the other hand, in order to expand its popularity and attract more colleges and universities to cooperate with them, domestic colleges and universities should actively improve and optimize the school website of the international education resources. Our colleges and universities can establish cooperative relations with the community, and take advantage of advanced technology to develop networkbased virtual university and open up overseas markets. China's agricultural universities can rely on the network of international cooperation to enhance the depth and breadth of education.

\section{E. Developing international cooperation in running schools actively.}

The international cooperation of higher education in the United States is more advanced, such as The University of Chicago, School of Business (MBA) has a branch in Barcelona, Spain, where the students studying can acquire the MBA degree from the University of Chicago; as another example, the United States have also set up branch campuses in Bulgaria, Azerbaijan and other countries to spread their culture to the world. The current situation of economic development is conducive to international cooperation of Chinese colleges and universities. The rapid economic development greatly enhance Chinese higher education level, which laid the foundation for solving the identify problems among different colleges and universities between China and foreign countries. In recent years, many colleges and universities in China have established cooperative education projects with foreign famous universities. It greatly promotes the internationalization of Chinese higher education. However, the colleges and universities should continue to expand the field and scale of Sino-Foreign cooperative education, make full use of foreign advanced experience in teaching and management, outstanding experts and other resources, and build an international teaching atmosphere for the majority of students.

\section{SUMMARY}

Under the background of economic development and globalization, it is imperative for China to internationalize the agricultural higher education. American successful experience of the internationalization higher education provides a useful reference for us. Based on the actual situation of Chinese higher education, we should put more emphasis on the foreign students' education, strengthen the international exchange of teachers, build the international curriculum system, strengthen the internationalization education by network technology, and actively develop international cooperation and so on. The development of Chinese higher education, especially agricultural higher education, is bound to bring a new prospect for it.

\section{REFERENCES}

[1] L. Wang, Experience and trend of the higher education internationalization in developed countries, Journal of Shandong Yingcai University, 9 (2013) 22-26.

[2] R. Yang, Internationalization of higher education in China, Spotlight on China, SensePublishers, (2016) 35-49.

[3] H. De Witt, Internationalization of higher education in the United States of America and Europe, IAP, 2009.

[4] P. Altbach, Perspectives on internationalizing higher education, International Higher Education, 27 (2015).

[5] J. He, Research on the strategies taken by Chinese universities to respond to internationalization of higher education-A case study of $\mathrm{H}$ University, East China Normal University, 2012.

[6] K. M. Callahan, The internationalization in student affairs in the United States from 1951 to 1996, Doctoral Dissertation, The Florida State University, 2015.

[7] P. G. Altbach, Global perspectives on higher education, JHU Press, 2016

[8] Y. Wang, T. Xu, Internationalization of American Higher Education and Its Production of Applied Talents, 6 (2012) 54-57.

[9] L. Siaya, International experience and knowledge in the United States, International Higher Education, 26 (2015).

[10] J. Knight, Internationalization brings important benefits as well as risks, International Higher Education, 46 (2015).

[11] D. K. Deardorff, V. G. Adinda, Outcomes assessment in the internationalization of higher education, The Sage handbook of international higher education, (2012) 167-190.

[12] A. Xie, Research on restriction factors and countermeasures about the Pioneer talents' raising of the higher agricultural colleges and universities, Hunan Agricultural University, 2007.

[13] T. Zhou, L. Xu, B. Li, Analysis and research of internationalized teaching of university, The Conference on Management Innovation, Intelligent Technology and Economic Development, 2012, 105-107. 